\title{
エンジン式超高圧パルス殺菌試験装置の水圧発生特性
}

\section{Characteristics on Water Pressure of Engine Type Liquid Sterilization Apparatus using Ultra High Pressure Pulse}

\author{
○学 紺野 隼（東邦大院）正 鈴木 実（東邦大） \\ Shun KONNO and Minoru SUZUKI
}

Toho University, 2-2-1 Miyama, Funabashi, Chiba, 274-8510 JAPAN

\begin{abstract}
Ultra high pressure underwater shock waves were applied to the sterilization of microbes. We used the imploding detonation of propane-oxygen to occur the ultra high pressure underwater shock waves. We investigated the imploding detonation using an engine type liquid sterilization apparatus having a precombustion chamber and two sample holders with inner volume of 5L. This apparatus can work $60 \sim 90$ $\mathrm{rpm}$ continuously and sterilize the water of $20 \mathrm{~m}^{3} / \mathrm{h}$. We investigated the pressure of underwater shock waves relation with engine speed and supplied pressure. We found that we could generate about $40 \sim 60 \mathrm{MPa}$ underwater shock waves in the sample holders.
\end{abstract}

Key Words: Imploding detonation, Underwater shock wave, Engine, Sterilization apparatus, Ultra high pressure plus.

\section{1.はじめに}

近年、プールや泠却水などの循環水、さらには船舶バラ スト水などの大規模水処理分野における殺菌方法は薬注法 が主流であるが、高コストや残留薬剤による環境負荷の増 大が課題となっている。我々は超高圧水中衝撃波の殺菌効 果に着目し、安価で環境に優しい液体殺菌装置の開発を目 標に、これまでに小型装置を用いた対象微生物への影響の 調查、さらには単発式大型装置における水中衝撃波の発生 特性について研究を行ってきた ${ }^{(1)}$ 。

本報では、連続運転が可能な大型エンジン式超高圧パル 又殺菌試験装置を試作し、本装置内での水圧発生特性につ いて調べた結果を報告する。具体的には、処理室下流端に おける衝撃水圧に及ぼすエンジンの回転数や予混合気吸気 圧力の影響を明らかにした。

\section{2. 実験装置と現象}

今回使用した大型エンジン式超高圧パルス殺菌試験装置 の組立図を Fig.1 に、外観写真を Fig.2に、それぞれ示す。 本装置はモータ駆動のピストンを備えたエンジン式となっ ており、予混合気混合タンク、シリンダ、ピストン、予燃 焼室が設置され、その後 2 系統に分かれ、それぞれトーナ
メント型爆轟誘導路、主燃焼室、処理室から構成される。 圧縮比は 7.0、予燃焼室容積 8L、主燃焼室容積 $0.65 \mathrm{~L}$ 、処理 室容積 5L、排気量は約 $7000 \mathrm{cc}$ である。予混合気は予燃焼 室上部に設置された混合タンクで旋回混合され、予燃焼室 から主燃焼室へと充填される。充填後、ピストンが上死点 付近に達した時、予燃焼室上部に設置されたスパークプラ グで着火される。燃焼波はトーナメント誘導路で加速され、 爆轟へと遷移する。そして、主燃焼室で収束し、超高温・ 超高圧状態となり、直接処理室内の液体に透過することで、 ガス圧から水圧への変換が行われ、高圧の水中衝撃波が発 生する。水中衝撃波発生後、処理室内に存在する微生物の 殺菌が行われる。なお、本報における衝擊水圧の計測は処 理室下流端に設置したキスラー社製圧カセンサ(6229A)で 計測し、チャージアンプを介して、オシロスコープに記録 して、測定した。本研究では、高圧の水中衝撃波を高効率 に発生させるため、気体収束爆薭及び過大爆轟を利用した。 気体収束爆霸は、発生した爆轟波を一点に収束させること で瞬間的に超高温・超高圧を発生させることができる(2)。 また、過大爆轟知焼室内で発生した先行波と反射波が 3 次元的に干涉することで、圧力が急激に上昇する現象であ る。

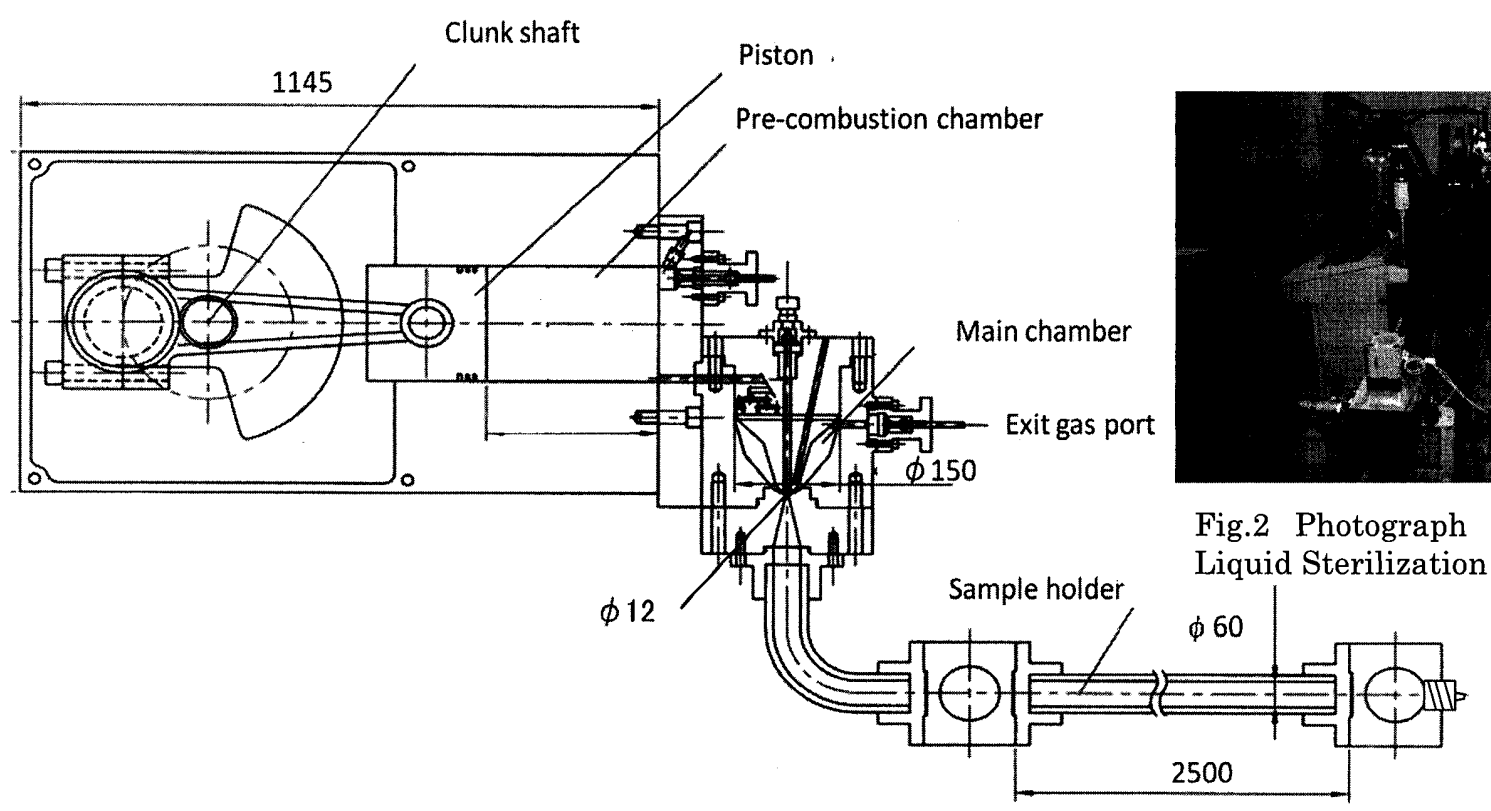

Fig.1 Engine Type Liquid Sterilization Apparatus. 
3. 実験結果

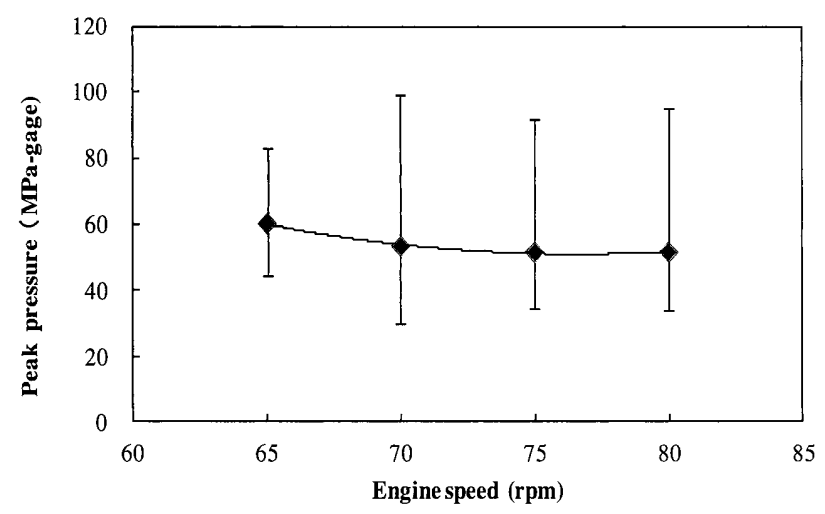

Fig.3 Relation of engine speed and peak pressures at the exit of sample holder.

エンジン回転数と処理室下流端における衝撃水圧の関係 を Fig. 3 示す。吸気圧力 $\mathrm{P} 0=0.3 \mathrm{MPa}$-gage、当量比 1.0 であ り、エンジン回転数は $65 \sim 80 \mathrm{rpm}$ である。Fig.3に示すよう に、衝撃水圧の平均値は 50 60MPa 程度となっており、工 ンジン回転数が衝撃水圧に及ぼす影響が比較的に小さいこ とが分かる。

Fig.4 には処理室下流端における衝撃水圧と吸気圧力の 関係を示す。当量比 1.0 、エンジン回転数 $65 \mathrm{rpm}$ に設定し た場合、吸気圧力を増加させることで、処理室下流端の衝 撃水压が上昇し、最大で $80 \mathrm{MPa}$ 、平均で 40 60MPa の衝撃 水圧を発生させることができた。吸気圧力 $0.1 \mathrm{MPa}$ 増加さ せることで、衝撃水圧は約 $10 \mathrm{MPa}$ 程度増加した。また、圧 力のバラツキは最大 $\pm 25 \mathrm{MPa}$ と比較的大きくなっている。

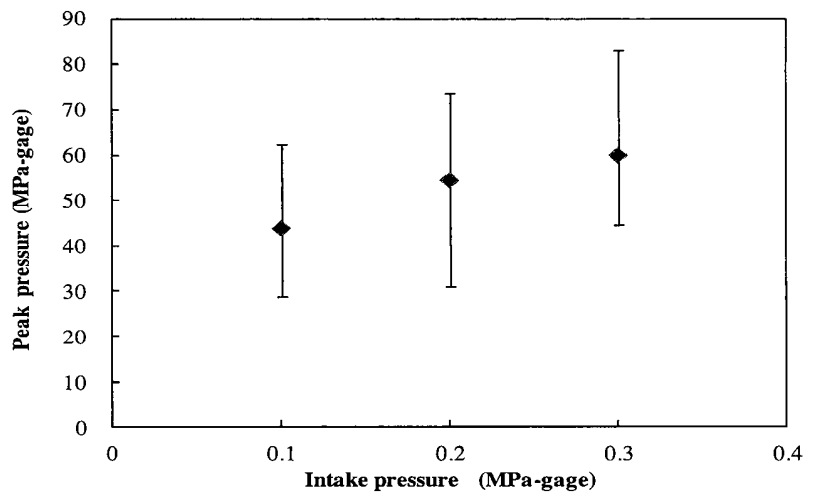

Fig.4 Relation of intake pressure and peak pressure at the exit of sample holder.

実験回数と衝撃水圧の実測值の時系列変化を Fig.5 に、 実験 1 回目之実験 3 回目の処理室下流端における衝撃水圧 を Fig.6に、それぞれ示す。エンジン回転数 $65 \mathrm{rpm}$ 、当量比 1.0 である。Fig.5 に示すように、衝撃水圧は実験 1,2 回目 で高く、それ以降は徐々に減衰し、40〜 $50 \mathrm{MPa}$ 程度になる。 また、Fig.6に示すように、実験回数を重ねるごとに、圧力 波形に変化が現れ、実験 1 回目では $500 \mu \mathrm{sec}$ 中に 3 つの波 が現れたのに対し、実験 3 回目では 7 つ波が現れた。こ のように、実験を重ねるごとに生じる圧力が徐々に低下し、 圧力波の山の数が増加した原因については、処理室内の水 がピストンの移動に伴う負圧によって吸引され、処理室内 の水面の高さが変動、又は燃焼室内に処理水の侵入したこ となどが考えられる。

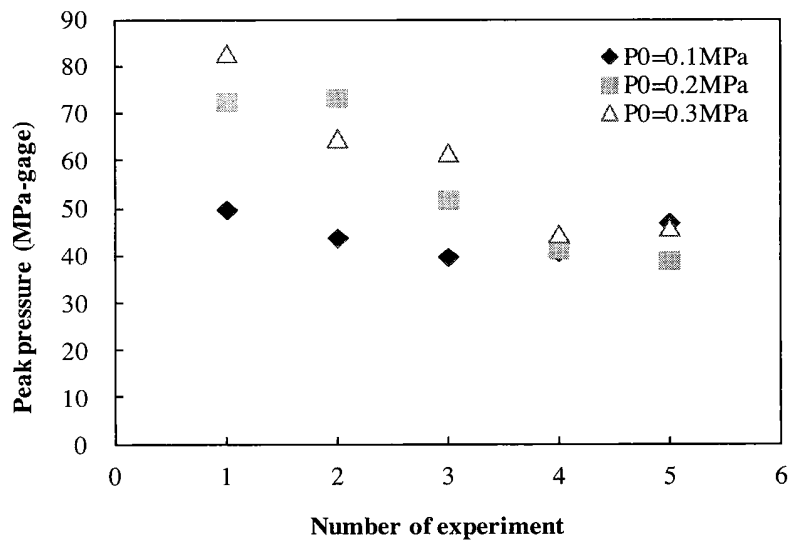

Fig.5 Relation of number of experiments and peak pressures at the end of sample holder.

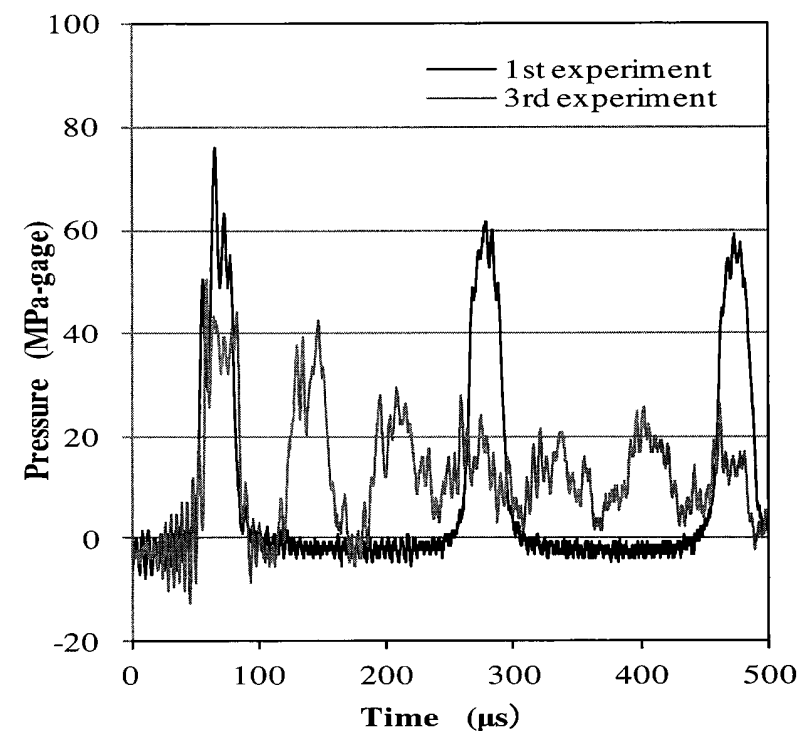

Fig.6 Pressure histories at the exit of sample holder. Peak pressures are about $75 \mathrm{MPa}\left(1^{\text {st }}\right.$ wave $)$ and $45 \mathrm{MPa}\left(3^{\text {rd }}\right.$ wave $)$.

\section{4.まとめ}

プロパン・酸素気体収束爆轟を駆動とするエンジン式超 高圧パルス殺菌試験装置の処理室下流端における衝撃水圧 とエンジン回転数、吸気圧力の影響を調べ、以下のことが 分かった。

(1)処理室下流端における衝撃水圧の值は、平均的に約 40 〜 $60 \mathrm{MPa}$ 程度である。

(2)予混合気の吸気圧力の上昇に伴い処理室下流端におけ る衝撃水圧が上昇する傾向にある。

(3)エンジン回転数を上げることで処理室下流端における 衝撃水圧が若干低下する傾向にある。

(4)実験を重ねることによる衝撃水圧の減衰及び圧力波が 多数発生する原因としては、ピストンの動きによる燃焼室 内圧の変動に伴う、処理水面の上下や処理水の燃焼室内一 の侵入が考えられ、これらが衝撃水圧のバラツキの原因と なっている。

\section{参考文献}

（1）鈴木実:気体収束爆轟による超高圧水中衝撃波の発生、 日本機械学会 2009 年度年次大会講演論文集.

（2）石井一洋、久保田倫弘、藤本寛幸、坪井孝夫、鈴木実： 収束デトネーションを用いたガスエンジン用点火シス テムに関する研究、日本機械学会論文集(B 編)、74 巻、 741 号(2008.5)pp1183 1190. 